УДК 811.161.2’373.7

DOI https://doi.org/10.26661/2414-9594-2021-1-9

\title{
ФРАЗЕОЛОГІЗМИ 3 КОМПОНЕНТОМ «СИН» В УКРАЇНСЬКІЙ ЛІНГВОКУЛЬТУРНІЙ ТРАДИЦІї
}

\author{
Демиденко Г. Г. \\ кандидат філологічних наук, \\ старший викладач кафедри української мови \\ Криворізький державний педагогічний університет \\ пр. Гагаріна, 54, Кривий Ріг, Дніпропетровська область, Україна \\ orcid.org/0000-0003-1494-2536 \\ gannaglebivna@gmail.com \\ Ковальова Г. М. \\ кандидат філологічних наук, \\ доиент кафедри мовної підготовки \\ Донбаська державна машинобудівна академія \\ вул. Академічна, 72, Краматорськ, Донецька область, Україна \\ orcid.org/0000-0002-0857-4493 \\ ganna-koval@i.ua
}

\begin{abstract}
Ключові слова: фразеологізм, ареальна фразеологія, лінгвокультурологічний аналіз, експресивностилістичне забарвлення, етнокультурна семантика, лінгвоментальність.
\end{abstract}

\begin{abstract}
У статті проаналізовано лінгвокультурні параметри фразеологізмів української мови з компонентом «син». Досліджено семантичні особливості сталих висловів, пов'язаних із традиційними сімейними цінностями, у контексті їх соціальної рефлексії. Внутрішня форма дібраних для розгляду фразем постає як культурно детермінований образ, що виражає не тільки знання й уявлення представників мовного колективу про родинні зв'язки, стосунки між батьками і дітьми, але й демонструє їх оцінку. Звернено увагу на те, що такі узвичаєні, загальновідомі витлумачення поняття «син» продиктовані національно зумовленими уявленнями про роль чоловіка і жінки в родині й суспільстві. Символічне навантаження й емоційний зміст аналізованих виразів, їхня репрезентація життєвих реалій, буденних i філософсько-повчальних прототипових ситуацій дає підстави зробити висновок: батьки та родина $є$ втіленням генетичного коріння людини, ii зв'язку 3 різними поколіннями. Прикметною рисою дібраних для мовного аналізу фразем є виразні семантико-експресивні нашарування, яскраві оцінні характеристики, які демонструють засудження, схвалення або відсутність чітко виражених характеристик, зумовлених соціально закоріненою оцінкою особи, здебільшого іï поведінки, інтелектуальних якостей, моральних рис, соціальних інтеракцій, зовнішності тощо. Помічено деяку амбівалентність у значенні виразів із компонентом «син», що полягає в різноплановості вживання фразеологізму (як у лайливому, фамільярному, загалом негативному контексті, так і для вираження доброзичливого, позитивного ставлення, захоплення).

3'ясовано специфікуекспресивно-стилістичного забарвлення фразеологізмів, зокрема через зіставлення загальномовних і регіональних лінгвоодиниць. Прокоментовано семантику, внутрішню форму й компонентний склад ареальних мовних зворотів, зважаючи на сферу побутування, ціннісні орієнтації, світоглядні уявлення, морально-виховні якості тощо. Розглянуті сталі вирази поєднують універсальне й ідіоетнічне відображення дійсності, фіксують територіальні лінгвоментальні риси українців.
\end{abstract}




\title{
PHRASEOLOGICAL UNITS WITH THE NOMINATIVE COMPONENT "SON" IN THE UKRAINIAN LINGUISTIC AND CULTURAL TRADITION
}

\author{
Demydenko G. H. \\ Candidate of Philological Sciences, \\ Senior Lecturer at the Ukrainian Language Department \\ Kryvyi Rih State Pedagogical University \\ Gagarin avenue, 54, Kryvyi Rih, Dnipropetrovsk region, Ukraine \\ orcid.org/0000-0003-1494-2536 \\ gannaglebivna@gmail.com \\ Kovaliova H. M. \\ Candidate of Philological Sciences, \\ Associate Professor at the Department of Language Training \\ Donbas State Engineering Academy \\ Academichna str., 72, Kramatorsk, Donetsk region, Ukraine \\ orcid.org/0000-0002-0857-4493 \\ ganna-koval@i.ua
}

Key words: phraseology, areal phraseology, linguistic and cultural analysis, expressivestylistic coloring, ethnocultural semantics, linguomentality.
The article analyzes the linguistic and cultural parameters of phraseology of the Ukrainian language with the nominative component "son". The paper focuses on semantic features of permanent expressions related to traditional family values in the context of their social reflection. The internal form of the idioms selected for consideration represents a culturally determined image, which expresses not only the knowledge and ideas of the native speakers about family ties, relations between parents and children, but also demonstrates their evaluation.

The symbolic load and emotional content of the analyzed idioms, their representation of life realities, everyday and philosophically instructive prototype situations give grounds to conclude that parents and family are the embodiment of human genetic roots, its connection with different generations.

Among the notable peculiarities of the phraseological units selected for linguistic analysis are the following: expressive semantic-expressive layers, vivid evaluative characteristics that demonstrate condemnation, approval or lack of clear characteristics due to socially ingrained evaluation of the person, mostly his behavior, intellectual qualities, morals, moral traits, social, etc. There is certain ambivalence in the meaning of set expressions with the nominative component "son", which consists in the diversity of the use of phraseology.

This research clarifies the specifics of expressive and stylistic coloring of phraseological units, in particular through the comparison of common language and regional linguistic units. The semantics, internal form and component composition of areal linguistic units are commented, taking into account the sphere of life, value orientations, worldviews, moral and educational qualities, etc. The analyzed constant inversions combine universal and idioethnic reflection of the reality, determine territorial linguistic features of Ukrainians. Areal phraseology in this case reflects not only the family and household fragments of life of Ukrainians, but also reveals the specifics of particular regions. Based on local traditions, cultural identity and national consciousness are formed in connection with the interpenetration of literary and colloquial language. The folk phraseology and dialectal speech practice, in particular preserve moral and aesthetic preferences and worldviews, which are important both for the perception of reality and own culture. 
Постановка проблеми. Системне вивчення української фразеології не лише спирається на міцний фундамент лінгвістичної науки, але й пов'язане 3 культурою окремого етносу, його психологією, побутовими реаліями, соціальними інтеракціями тощо.

Активність наукового пошуку в царині лінгвокультурології із проєкціями на фразеологічний фонд мови, без сумніву, є виправданою, оскільки сталі звороти є потужним джерелом пізнання й осмислення світу. Вони побутують у мовленні як витончені, влучні, змістовні засоби для опису ментальних рис, характеру, способу освоєння світу певною етнічною спільнотою. Н. Шарманова слушно зазначає: «Особливості національного характеру знаходять вираження в мікрополі споконвічних утворень на позначення найбільш суттєвих, вічних, визначальних, архетипних для українців понять земля, мати, хата. Кожне із цих слів-понять має розгалужену систему прямих і непрямих значень, характеризується широкими асоціативними зв'язками, здатністю до метафоризації, персоніфікації, винятковими можливостями включатися в різноманітні контексти, утворюючи стійкі звороти» $[1$, c. 74$]$. У зв'язку із цим можна стверджувати, що в такій системі понять окремої ваги набувають й дотичні до названих образи-архетипи: батько, син, дочка та інші. Така думка є закономірною, зважаючи на те, що однієї зі сфер первісного функціонування прототипів українських фразем є життя української родини, стосунки батьків і дітей, які в українській мовній свідомості набувають національно-культурних нашарувань.

Натепер у лінгвістичних розвідках найгрунтовніше досліджено концепти «батько», «мати», «материнство» (Н. Венжинович, Г. Демиденко О. Завірющенко, Ж. Колоїз, А. Рижкіна, М. Сіренко, О. Трумко, А. Чернова й інші), «діти», «дитина» (В. Калько, О. Мороз), «родина», «сім'я» (А. Рижкіна, Ю. Макарець, О. Сліпчук), родинні зв'язки загалом розглянуто на матеріалі прислів 'їв і приказок із порівняльним компонентом (Г. Доброльожа [2]), фрагментарно вивчено і концепт «син» у міжмовних паралелях (В. Ярмак [3]).

Мета статті полягає в аналізі семантичних рис, експресивно-емоційного забарвлення фразеологізмів із компонентом син у контексті української лінгвокультури.

Виклад основного матеріалу дослідження. Сталі вислови 3 компонентом син характеризуються особливою внутрішньою організацією, образною основою, детермінованою передусім лексичним значенням слова син, а саме: «1) особа чоловічої статі стосовно своїх батьків; 2) нащадки, молоде покоління (у множині); 3) ласкаве звертання літньої або дорослої людини до молодого за віком чоловіка, юнака, хлопчика;
4) людина чоловічої статі щодо свого духівника або особи духовного сану; 5) людина як уродженець, житель якої-небудь країни, місцевості, представник якоїсь національності // Вихованець когось, чогось; людина, кровно, тісно зв'язана 3 ким-, чим-небудь. // Нащадки, послідовники, земляки. // Людина, на якій відбилися характерні, типові риси iï часу, епохи, середовища і т. ін. // Поборник, служитель, представник чогось» $[4$, с. 1316]. Син у родині, за народними уявленнями, - більш бажана дитина, ніж донька, адже він - продовжувач батьківського роду [5, с. 538]. Звідси, відповідно, цілком вмотивованою $є$ фразема батьків (отецький) син - «1) спадкоємець заможних батьків; 2) син від законного шлюбу» [6, с. 646], хоч у семантиці вислову констатуємо уточнення про майновий стан родини, походження дитини чоловічої статті, що, очевидно, свідчить про соціальний статус (на відміну від позашлюбних дітей).

Варто відзначити, що кількість зафіксованих лінгвоодиниць $є$ досить обмеженою, однак семантика відібраних фразеологічних одиниць (далі ФО) досить строката, подекуди конотація висловів втрачає зв'язок зі стрижневим компонентом син. Отже, стійке уявлення про традиційні родинні стосунки в українській етнокультурі набуває змін, акумулює знання про життя, побут, особливості професії, міжособистісне спілкування тощо, 3 якими пов'язаний набір імпліцитних сем, як-от: покаяння, незадоволення, схвалення, часовий вимір, виховання, мораль, риси характеру тощо.

3-поміж проаналізованих сталих зворотів звертаємо увагу на біблійний вислів блудний син, що означає «той, хто повертається з каяттям, визнанням своїх провин» [6, с. 646], адже блудний син це прообраз грішника, якого кличе Бог до Свого Отчого дому [7, с. 11]. На Поліссі ця загальновідома біблійна фразема набуває інших семантичних відтінків, втрачає безпосередній зв'язок iз біблійною притчею про сина, який залишив батьківський дім у пошуках розваг і самостійного безвідповідального життя, але повернувся до батька й отримав його прощення. У ареальному мовленні поліщуків ФО блудний син уживається стосовно людини, яка не підкоряється сімейним традиціям $[8$, с. 160]. У лемківських говірках фіксуємо фразеологізм піти як блудний син у значенні «безслідно пропасти» [9, с. 121].

Декілька висловів вирізняються зниженим стилістичним планом і вживаються в контексті лайки здебільшого для вираження незадоволення ким-небудь, подекуди з фамільярним звучанням, а саме: бісів (дияволів, чортів) син [6, с. 646], сякий-[не]-такий син [6, с. 647]. У семантико-стилістичному плані можемо схарактеризувати амбівалентність виразу вражий син [6, с. 646], яким в одному зі значень мовець може послуговуватися, 
демонструючи своє доброзичливе, позитивне ставлення до когось, захоплення кимось. У говірках Житомирщини цей сталий зворот використовуються мовцями для висловлення свого незадоволення кимось [8, с. 160].

Зниженого стилістичного забарвлення набуває і фразема на якого (бісового) сина [6, с. 46], де емоційно-експресивне забарвлення забезпечує означення бісовий $\leftarrow$ біс - «уявна надприродна істота, що втілює зло і звичайно зображується у вигляді людини з козячими ногами, хвостом і ріжками, злий дух, чорт, диявол, сатана» [4, с. 85]. Не позбавлений стилістичного забарвлення й фразеологізм страшків син, який передає іронічне ставлення до боязкої, лякливої людини, що відчуває страх у будь-якій ситуації [6, с. 646]. Натомість на Буковині побутує антонімічний вираз не (ни) страшків син, що характеризує сміливу людину [10, с. 155], яка не перебуває у стані хвилювання, тривоги чи неспокою, не знає страху в якійсь справі, має сильну, відважну вдачу.

Дібраний фактичний матеріал ілюструє окремі соціально-побутові явища. Наприклад, віковий діапазон співрозмовників реалізований у вислові в сини годитися [6, с. 154]; недостатній рівень виховання, соціалізації, культурної грамотності репрезентує фразема дитя (дитина, син) природи [6, с. 200], що має у складі лексему син лише як варіативну частину. Фразеовербалізм сімейно-побутових реалій мамин синок [6, с. 467] дає вичерпну характеристику несамодостатньої особи, здебільшого хлопчика або юнака, розпещеного, позбавленого самостійності в діях і вчинках. У регіональному мовленні волинян побутує вираз мамин синочок у значенні «сором'язливий хлопець» [11, с. 375], яке не зафіксовано в академічному фразеологічному словнику. Як бачимо, названа лінгвоодиниця вживається $з$ демінутивним суфіксом -очок-, що демонструє позитивну суб'єктивну, зменшено-емоційну оцінку дитини чоловічої статі.

Народні уявлення про риси характеру чи особливості зовнішності людини репрезентують окремі ареальні фраземи. Скажімо, у південно-східних регіонах вислів причепилівський син, що означає «причіплива людина» [12, с. 453], $\epsilon$ цілком умотивованим у семантичному плані. Натомість можемо припустити, що певну деградацію в родині, пов' язану з порядком появи дітей на світ, репрезентує зневажливий вираз ванька третій син [12, с. 82], коли йдеться про дивакувату людину, дурня. У фразеології лемківських говірок на позначення відповідних низьких розумових та інтелектуальних можливостей людини побутує лайливий вислів тру́манув син [13, с. 211; 9, с. 121$].$ На Волині вживаним є ФО скурвий син [11, с. 147], що демонструє моральні якості людини, яка зневажила родинні цінності, шлюбні обітниці та є невірною в подружньому житті. Зауважимо, що прикметник скурвий називає розпусну людину, а вислів скурвий син може вживатися у значенні «син розпусної жінки» [14, с. 2435]. На території Житомирської області використовують вислів рости, сину, хоч дурний, але великий [8, с. 160], коли мають на меті схарактеризувати розумові здібності нездібної до чогось людини. У буковинських говірках у зневажливому, згрубілому значенні побутує фразема фулейський син, яка іменує

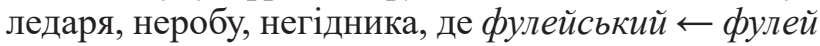
запозичено з румунської мови (falit - «банкрот», «неспроможний боржник») [10, с. 217].

Деякі фізичні вади вербалізовано у вислові кавалериста син [12, с. 231], що називає кривоногу від народження людину (пор. колесо між ніг $[12$, с. 453]), i, припускаємо, вона отримала такі «особливості» від батька, прототипом якого для утворення цього фразеологізму став образ кавалериста, тобто того, хто служить у кавалерії, кіннотника. Відповідно, людина такої професії, повсякчас перебуваючи верхи на коні, мала вигляд кривоногої. Подекуди схожу прототипову ситуацію можна реконструювати й для витлумачення внутрішньої форми вислову син футболіста $[12$, c. 453$]$, який також має стосунок до людини зі специфічними ногами (можливо, форма, рухи, травми, постава) i пов'язаний із професійною діяльністю футболістів.

Ареальна фразеологія почасти відображає не тільки родинно-побутові фрагменти життя українців, але й розкриває географічну, промислову специфіку окремих регіонів. Так, про вугільну галузь східних областей ідеться у вислові шахтарський син, яким називають дуже брудну людину [12, с. 453]. Як відомо, гірники працюють у важких умовах, отже, у процесі видобутку вугілля їх одяг і тіло покриваються чорним пилом.

На окреме коментування заслуговують фраземи, що вживаються для називання міри і ступеня, якості чогось, як-от зафіксований у східних говірках вислів у синячий голос, тобто «дуже пізно, несвоєчасно» [12, с. 140], утворений, як нам видається, за зразком інших лінгвоодиниць аналогічної семантики (у свинячий голос [12, с. 140], y псячі голоси $[12$, с. 140]). В академічному словнику натрапляємо на вираз до сина [6, с. 467], який подається у словниковій статті 3 позначкою «застарілий» і позначає велику кількість чогось. Сучасному мовцю важко витлумачити етимологію цього сталого звороту, який перейшов до пасивного фразеологічного складу, можемо припустити, що смисловий діапазон зосереджений на вагомості сина в родині як бажаної, очікуваної дитини або пов'язаний із фінансовими витратами батьків після народження дитини. Влучним прикладом є ілюстрація, подана у словнику, із твору 
Г. Квітки-Основ'яненка: Нема того на світі, чого не було на тому ярмарку, і якби грошей до сина, то накупив би усього [6, с. 467].

Висновки. Отже, аналіз мовних фактів дав змогу засвідчити культурно-національну інформацію фразем із компонентом син, в основу яких покладено уявлення не тільки про світ української родини, а й про різні аспекти життя людини, її зовнішність, вдачу, розумові здібності тощо. Компонентний склад досліджуваного матеріалу створює особливе експресивно-стилістичне забарвлення лінгвоодиниць, надає їм різноманітних конотацій згрубілості, вульгарності, увиразнює народну фразеологію різних регіонів України.

\section{ЛІТЕРАТУРА}

1. Шарманова Н. Етнолінгвістика : навчальний посібник для студентів факультету української філології / за ред. Ж. Колоїз. Кривий Ріг : НПП «Астерікс», 2015. 192 с.

2. Доброльожа Г. Світ української родини у прислів'ях та приказках з порівняльним компонентом. Волинь - Житомирщзина. 2002. № 9. С. 137-141.

3. Ярмак В. Семантико-експресивний потенціал концепту «син» у сербських, російських і українських фразеологізмах та пареміях. Мова і культура. Київ, 2011. Вип. 14. Т. 7. С. 47-56.

4. Великий тлумачний словник сучасної української мови / уклад. і голов. ред. В. Бусел. Київ ; Ірпінь : ВТФ «Перун», 2009. 1736 с.

5. Жайворонок В. Знаки української етнокультури : словник-довідник. Київ : Довіра, 2006. 703 с.

6. Словник фразеологізмів української мови / уклад. В. Білоноженко та ін. Київ : Наукова думка, 2003. 1104 с.

7. Колоїз Ж., Бакум 3. Слово Благовісті. Словник-довідник фразем біблійного походження. Кривий Ріг : I. B. I., 2002.96 c.

8. Доброльожа Г. М. Фразеологічний словник говірок Житомирщини. Житомир : ПП Туловський, 2010. $404 \mathrm{c}$.

9. Вархол Н., Івченко А. Фразеологічний словник лемківських говірок Східної Словаччини. Братислава : Словацьке педагогічне вид-во. Відділ укр. літ-ри у Пряшеві, 1990. 160 с.

10. Словник фразеологізмів та паремій Чернівеччини : матеріали до словника фразеологізмів та паремій Чернівеччини / уклад. Г. Кузь та ін. Чернівці : Чернівецький нац. ун-т імені Юрія Федьковича, 2017. $352 \mathrm{c}$.

11. Мацюк 3. Що сільце, то нове слівце : словник фразеологізмів Західного Полісся. Луцьк : Вежа-Друк, 2013. 476 с.

12. Ужченко В., Ужченко Д. Фразеологічний словник східнослобожанських і степових говірок Донбасу. Луганськ : Вид-во ДЗ «ЛНУ ім. Тараса Шевченка», 2013. 552 с.

13. Ступінська Г., Битківська Я. Фразеологічний словник лемківських говірок / за ред. Г. Ступінської, В. Ступінського. Тернопіль : Навчальна книга - Богдан, 2013. 464 с.

14. Словарь української мови : у 4-х т. / зібр. ред. журн. «Киевская Старина» ; упоряд. Б. Грінченко. Репр. відтворення вид. 1907-1909 рр. Київ : Вид-во АН УРСР, 1958-1959. Т. 4 : Р - Я. 1958. 564 с.

\section{REFERENCES}

1. Sharmanova N.M. (2015) Etnolinhvistyka: navchalnyi posibnyk dlia studentiv fakultetu ukrainskoi filolohii [Ethnolinguistics: a textbook for students of the Faculty of Ukrainian Philology]. Kryvyi Rih: NPP ASTERIKS. (in Ukrainian).

2. Dobrolozha H. (2002) Svit ukrainskoi rodyny u prysliviah ta prykazkah z porivnialnym komponentom [The world of the Ukrainian family in proverbs and sayings with a comparative component]. Volyn Zhytomyrshchyna, vol. 9, pp. 137-141.

3. Yarmak V.I. (2011) Semantyko-ekspresyvnyi potentsial kontseptu "syn" u serbskyh, rosiiskyh i ukrainskyh frazeolohizmah ta paremiiah [Semantic and expressive potential of the concept of "son" in Serbian, Russian and Ukrainian phraseology and paremias]. Mova i kultura, vol. 14, № 7. Pp. 47-56.

4. Busel V.T. (ed.) (2009) Velykyi tlumachnyi slovnyk suchasnoi ukrainskoi movy [Large explanatory dictionary of the modern Ukrainian language]. Kyiv - Irpin: VTF Perun. (in Ukrainian).

5. Zhaivoronok V. (2006) Znaky ukrainskoi etnokultury: slovnyk-dovidnyk [Signs of Ukrainian ethnoculture: dictionary-reference book]. Kyiv: Dovira. (in Ukrainian).

6. Bilonozhenko V.M. (ed.) (2003) Slovnyk frazeolohizmiv ukrainskoi movy [Dictionary of phraseology of the Ukrainian language]. Kyiv: Naukova dumka. (in Ukrainian).

7. Koloiz Zh.V., Bakum Z.P. (2002) Slovo Blahovisti. Slovnyk-dovidnyk frazem bibliinoho pohodzhennia [The word of the Gospel. Dictionary of phrases of biblical origin]. Kryvyi Rih: I. V. I. (in Ukrainian).

8. Dobrolozha H.M. (2010) Frazeolohichnyi slovnyk hovirok Zhytomyrshchyny [Phraseological dictionary of dialects of Zhytomyr region]. Zhytomyr: P.P. Tulovskyi. (in Ukrainian). 
9. Varhol N.D., Ivchenko A.I. (1990) Frazeolohichnyi slovnyk lemkivskyh hovirok Shidnoi Slovachchyny [Phraseological dictionary of Lemko dialects of Eastern Slovakia]. Bratyslava: Slovatske pedahohichne vyd-vo. (in Ukrainian).

10. Kuz H., Rusnak N., Skab M., Tomusiak L. (2017) Slovnyk frazeolohizmiv ta paremii Chernivechchyny: materialy do slovnyka frazeolohizmiv ta paremii Chernivechchyny [Dictionary of phraseology and paremias of Chernivtsi region: materials for the dictionary of phraseology and paremias of Chernivtsi region]. Chernivtsi: Chernivetskyi nats. un-t imeni Yuriia Fedkovycha. (in Ukrainian).

11. Matsiuk Z. (2013) Shcho siltse, to nove slivtse: slovnyk frazeolohizmiv Zakhidnoho Polissia [What is a village is a new word: a dictionary of phraseological units of Western Polissya.]. Lutsk: Vezha-Druk. (in Ukrainian).

12. Uzhchenko V.D., Uzhchenko D.V. (2013) Frazeolohichnyi slovnyk shidnoslobozhanskyh i stepovyh hovirok Donbasu [Phraseological dictionary of East Slobozia and steppe dialects of Donbass]. Luhansk: DZ "LNU im. Tarasa Shevchenka". (in Ukrainian).

13. Stupinska H.F. Bytkivska Ya.V. (2013) Frazeolohichnyi slovnyk lemkivskykh hovirok [Phraseological dictionary of Lemko dialects]. Ternopil: Navchalna knyha - Bohdan. (in Ukrainian).

14. Hrinchenko B. (ed.) Slovar ukrainskoi movy: $u 4 t$. [Dictionary of the Ukrainian language]. Repr. vidtvorennia vyd. 1907-1909 rr. Kyiv: AN URSR. (in Ukrainian). 